\title{
Law Enforcement Against Handling Traffic Accidents Through Non Line Under Penal of Legal Culture of Indonesian Police in Kudus
}

\author{
Ngatmin $^{1}$ and Umar Ma'ruf ${ }^{2}$
}

Abstract. The Police of the Republic of Indonesia (POLRI) is a tool that contributes to maintaining state security and public order. The purpose of this research: knowing and analyzing the traffic accident set in the current positive criminal law further handling traffic accidents and then through non penal later barriers and settlement solutions handling traffic accidents then then through non penal.

This research is legal using empirical juridical approach or commonly referred to as the Juridical Sociological. According to his level, the study was specified as descriptive analytical research.

The results of this study are (1) In the conduct of law enforcement against traffic criminal offenses remain consistent with the provisions of the Criminal Code and Act No. 22 Of 2009 regarding Traffic and Road Transportation. (2) Allowing involved to make peace (3) Barriers handling track non penal offenders and victims and their families do not support the settlement outside the court, the solutions do is keep highlighting persuasive conclusion in this research that law enforcement against criminal acts and cross remains consistent with the provisions of the Criminal Procedure Code and Act No. 22 of 2009 on Traffic and Transportation, opportunity for the parties involved to make peace. Perpetrators and victims of personal character that does not support the settlement outside the court.

Keywords: Law Enforcement; Traffic Accident; Non Line Penal Of Legal Culture.

\section{Introduction}

Indonesia referred to as the rule of law (rechtstaat), and not the State power (machstaat), as defined in the Company Act of 1945. The Republic of Indonesia (hereinafter Article 1 (3) of the Constitution of 1945 affirms that Indonesia is a country of law, implies that every order of life of the nation, society and the state is based on law.

According to Lawrence $M$. Friedmann, legal input is a shock wave in the form of demands by the community, which in turn drive the legal process. Friedmann continued that the majority of jurists concentrated to outputs of law, so understanding the formation of a product is a comprehensive legislation. ${ }^{3}$ Problems syncing is not just limited to the discrepancy between the legislation per se, but associated with the overall system of law applicable in Indonesia.

The Police of the Republic of Indonesia (POLRI) is a tool that contributes to maintaining state security and public order, law enforcement, protection, shelter, and service to the community, the police are required to continue to develop into a more professional and closer to the people. When completing a traffic accident case, every member of the police have no attachment to the norms or rules to carry out its obligations as law enforcement. ${ }^{4}$

\footnotetext{
${ }^{1}$ Student of Master of Law, Universitas Islam Sultan Agung Semarang and Member of Police, email: ngatminwsn@gmail.com

${ }^{2}$ Lecture of Faculty of Law UNISSULA Semarang

${ }^{3}$ Lawrence M. Friedmann, 2011. The Legal System: A Social Science Perspective, [Pent. M. Khozim], Nusamedia, Bandung, p. 3.

${ }^{4}$ Sudikno Mertokusumo,1999. Mengenal Hukum Suatu Pengantar. Liberty, Yogyakarta, p. 16
} 
Based on the description on the background of the above problems can be formulated issues: regulation of traffic accidents or the authority of the Police in handling traffic accidents. Handling traffic accident and then through non penal based Indonesian legal culture in the Kudus Police. Obstacles and solutions in the settlement process of handling traffic accidents and then directly through the non penal based Indonesian legal culture in the Kudus Police.

The aim of this research is to know and analyze the arrangement of a traffic accident or the authority of the Police in handling traffic accidents, investigate and analyze the handling of accidents and then through non penal based Indonesian legal culture in the Kudus Police. Identify and analyze the barriers and any solution in the settlement process of handling traffic accidents and then directly through the non penal based Indonesian legal culture in the Kudus Police

\section{Research methods}

This research is legal using empirical juridical approach or commonly referred to as the Juridical Sociological. To analyze qualitatively traffic enforcement by the Kudus Police Traffic Unit in order to reduce the number of traffic accidents in the sanctuary. ${ }^{5}$ This study is specified as descriptive analytical research to provide a detailed description, systematically and comprehensively on all matters relating to traffic enforcement in suppressing the number of traffic accidents in the jurisdiction of the Kudus Police.

Methods of data analysis used in this study is a qualitative analysis, which is a way of analysis of the results of research that produces descriptive data analytical, that the data stated by the respondent in writing or orally as well as the behavior of the real, which is researched and studied as a whole. ${ }^{6}$ The material and data are then analyzed the traffic law enforcement in reducing the number of traffic accidents in the jurisdiction of the Kudus Police.

\section{Results And Discussion}

\subsection{Traffic Accidents Are Regulated In The Current Of Positive Criminal Law}

Traffic accident is an occurrence that is very difficult predict when and where it happened. Accidents not only cause trauma, injury, or disability but can lead to death. Difficult cases of accidents is minimized and tend to increase as the number of road length and movement of the vehicle. Based on the definition of an accident that traffic accident is an event that is unexpected or unpredictable and undesirable caused by motor vehicles, occurred on the highway, or in open spaces that serve as a means of traffic seerta cause damage, injuries, human deaths and loss of property.

The process of settlement of criminal case of traffic accidents are subject to the rules of the Criminal Procedure Code, which as investigators, Kudus police officers have the authority as stipulated in Article 7 (1) Criminal Code, namely:

- Receive reports or complaints from one of criminal activity;

- Perform the first act at the moment in the scene;

- Says stop a suspect and check the personal identification of the suspect;

\footnotetext{
${ }^{5}$ Mukti Fajar ND dan Yulianto Achmad, 2010, Dualisme Penelitian Hukum Normatif \& Empiris, Pustaka Pelajar, Yogyakarta, p 47.

${ }^{6}$ ibid, p.192.
} 
- Arrest, detention, search and seizure;

- Perform inspection and seizure of the letter;

- Taking fingerprints and a photograph;

- Calling people to be heard and questioned as a suspect or a witness;

- Bring in the necessary expertise in relation to the case investigation;

- Conducting investigations termination;

- Other actions held legally responsible.

Kudus police investigator until the month of October 2018 found there were 541 cases of traffic accidents, but there are only 9 cases were transferred to the Public Prosecutor or the P-21. While many cases of traffic accidents were settled out of court or through the concept of Alternative Dispute Resolution (ADR)

Table 1.1

Data Traffic Accident Case Genesis in the Kudus Resort in 2015-2018

\begin{tabular}{|c|c|c|c|c|}
\hline Year & Event & P21 & ADR & SP3 \\
\hline 2015 & 633 & 3 & 621 & 9 \\
\hline 2016 & 757 & 4 & 729 & 24 \\
\hline 2017 & 685 & 8 & 599 & 78 \\
\hline 2018 & 541 & 9 & 426 & 64 \\
\hline
\end{tabular}

Source: Police, Kudus, 2018

Provisions concerning traffic accident already regulated under Act No. 22 Of 2009 regarding Traffic and Road Transportation under Article 310 and Article 311. The provisions of Article 310. Any person driving a motor vehicle due to negligence has caused a traffic accident with:

- Damage to the vehicle and / or goods, shall be punished with imprisonment for a period of 6 (six) months and / or a maximum fine of Rp. 1.000.000, -

- Minor injuries and damage to vehicles and / or goods, shall be punished with imprisonment for a period of 1 (one) year and / or a fine of Rp.2.000.000, -.

- Severe injuries, shall be punished with imprisonment of 5 (five) years and / or a fine of Rp.10.000.000, - , in the case of such accidents resulted in another person died shall be punished with imprisonment of six (6) years and / or a maximum fine of $\mathrm{Rp}$. 12.000.000, -

The provisions of Article 311 of the traffic accident states: Any person who knowingly driving a motor vehicle in a manner and circumstances that endanger the lives or goods shall be sentenced to imprisonment for a period of 1 (one) year or a fine of not more Rp.3.000.000, -. In the event that such actions result in a traffic accident with:

- Damage to the vehicle and / or goods, the offender shall be punished with imprisonment for a period of 2 (two) years or fine of not more Rp.4.000.000, -.

- Minor injuries and damage to vehicles and / or goods, shall be punished with imprisonment for a period of 4 (four) years or fine of not more Rp.8.000.000, -.

- Severe injuries, shall be punished with imprisonment of ten (10) epidemic or a fine of Rp.20.000.000, -, in the case of such accidents resulted in another person died shall be punished with imprisonment of twelve (12) years or fine most Rp.24.000.000, -

\subsection{Settings About Traffic Accident Or Authority Police in Handling Traffic Accidents}

Forms of Kudus police discretion in the case of traffic accidents is through penal mediation 
by way of seeking a settlement between the parties involved by peaceful means through the mechanism of Alternative Dispute Resolutions/ADR. Investigators provide an opportunity to the litigant parties to the peace agreement. ${ }^{7}$

The first factor according to Chief of Unit Laka Police Kudus is internally the Letter Kapolri Nopol B / 3022 / XII / 2009 / Sdeops 14 December 2009 concerning the handling of cases through Alternative Dispute Resolution (ADR) Police of the Republic of Indonesia Central Java Regional Directorate of Traffic provides guidelines of ADR in the case of a traffic accident in which the classification of cases that can be in ADR among others also includes the case file has been declared complete by the Public Prosecutor or Q21 to deaths and severe injuries.

It is in the public interest, which the The Police of the Republic of Indonesia officers in performing their duties and authority to act according to his own judgment and only performed in a state that really needs to pay attention to legislation and code of ethics of Police Profession. ${ }^{8}$

The basics are used by police officers Kudus through peace / Alternative Dispute Resolutions with the classification of the crime of traffic accidents with material damage, minor injuries, serious injuries and even death. Besides the two underlying factors Kudus police are applying to use their discretion Article 16 (2) The Police Act which stated the police can perform other actions by law responsible. Proper consideration based on the circumstances that force and to respect human rights ${ }^{9}$.

The first factor behind the use of discretion in the form of penal normative mediation can be traced back to the article 236 (2) UULLAJ where in certain cases of traffic accidents can be settled out of court. The indicators used to describe the Article 236 paragraph (2) UULLAJ are minor injuries suffered by the victim in the near future a speedy recovery and do not cause injury remains, the case does not lead to social unrest, accidents involving victims of mass and material damages caused very little.

Furthermore, application of discretion in Article 18 of the Police Act was not only used for minor traffic accident case only as provided for in Article 236 paragraph (2) UULLAJ. Factors behind the use of ADR to the crime of traffic accidents with material damage, minor injuries, serious injuries and even death is recognized by the Chief of Unit Laka Polresta Kudus addition to the command of the National Police Headquarters and the Central Java Police is for purely humanitarian reasons and culture Kudus not want a convoluted process and tend to choose the path of peace.

\subsection{Obstacles And Solutions In The Settlement Process Of Handling Traffic Accidents And Then Directly Through The Non Penal Based Indonesian Legal Culture In The Kudus Police}

The use of discretion in handling traffic accidents settlement then necessarily through their non penal is necessary supervisory and monitoring investigators to monitor the development of the investigation from being misused by monitoring internal

\footnotetext{
7 Interview with Inspector Ngatmin, S..H, Head of the Traffic Police Accident Unit of the Kudus, November 12, 2018

${ }^{8}$ Guidance on the ADR in the case of a traffic accident, the Directorate of Traffic Police of the Republic of Indonesia Central Java region in 2010.

${ }^{9}$ Ibid.
} 
investigations conducted in phases and is attached to each investigator. So, we need mental coaching to members of the police continuously in order to change the mindset in dealing with traffic accidents.

In the category of the crime of traffic accident light, a mechanism that is done by the police is right, because it is in conformity with the provisions of Article 236 paragraph (2) UULLAJ that provides opportunities process of settling disputes outside the court, although the mechanism is not arranged in UULLAJ however Police Chief Letter Nopol B / 3022 / XII / 2009 / Sdeops 14 December 2009 concerning the handling of cases through Alternative Dispute Resolution (ADR) can be used as a reference in completing the crime of minor traffic accidents. However, if explored further, for criminal offenses and criminal offenses accident was severe accidents with severe injuries and died, the mechanism does not use its discretion in accordance with the Criminal Procedure Code and even UULLAJ.

\section{Closing}

\subsection{Conclution}

- Settings About Traffic Accident Or Authority Police in Handling Of Traffic Accidents Provisions concerning traffic accident already regulated under Act No. 22 of 2009 regarding Traffic and Road Transportation under Article 310 and Article 311. The provisions of Article 310. Any person driving a motor vehicle due to negligence has caused a traffic accident with:

- Damage to the vehicle and / or goods, shall be punished with imprisonment for a period of 6 (six) months and / or a maximum fine of Rp. 1.000.000, -

- Minor injuries and damage to vehicles and / or goods, shall be punished with imprisonment for a period of 1 (one) year and / or a fine of Rp.2.000.000, -.

- Severe injuries, shall be punished with imprisonment of 5 (five) years and / or a fine of Rp.10.000.000, -, in the case of such accidents resulted in another person died shall be punished with imprisonment of six (6) years and / or a maximum fine of Rp. 12.000.000, -

The provisions of Article 311 of the traffic accident states: Any person who knowingly driving a motor vehicle in a manner and circumstances that endanger the lives or goods shall be sentenced to imprisonment for a period of 1 (one) year or a fine of not more Rp.3.000.000, -. In the event that such actions result in a traffic accident with:

- Damage to the vehicle and / or goods, the offender shall be punished with imprisonment for a period of 2 (two) years or fine of not more Rp.4.000.000, -

- Minor injuries and damage to vehicles and / or goods, shall be punished with imprisonment for a period of 4 (four) years or fine of not more Rp.8.000.000, -.

- Severe injuries, shall be punished with imprisonment of ten (10) epidemic or a fine of Rp.20.000.000, -, in the case of such accidents resulted in another person died shall be punished with imprisonment of twelve (12) years or fine most Rp.24.000.000, -.

- Handling Traffic Accident and Through Non Penal Based Indonesian legal culture in the Kudus Police.

Forms of Kudus police discretion in the case of traffic accidents is through penal mediation by way of seeking a settlement between the parties involved by peaceful means through the mechanism of Alternative Dispute Resolutions / ADR. Investigators 
provide an opportunity for parties litigant to conduct peace agreement It is in the public interest, which the official The Police of the Republic of Indonesia (POLRI) in carrying out their duties and authority to act according to his own judgment and only performed in a state that really needs to pay attention to the laws and codes of conduct police profession. Furthermore, application of discretion in Article 18 of the Police Act was not only used for minor traffic accident case only as provided for in Article 236 paragraph (2) UULLAJ.

\subsection{Suggestion}

Suggestions in this study are as follows:

- The police as law enforcement officers are advised continuously improve the professionalism and capacity as executor of the peace process between the parties involved in criminal cases of traffic, by continuing to hone the potential that some training to adapt to the development of peace technique. This is important in order to maximize the goals of peace, namely finding solutions to disputes and conflicts in the society.

- Police in the mediation process are advised to proportionally position ourselves as a neutral party, so as to avoid the appearance of taking sides against one of the parties. It is important to keep the peace process going on between the two sides really guided by good intentions and a sincere desire on both sides, and still based on a sense of justice for the people.

\section{Bibliography}

[1] Lawrence M. Friedmann, 2011, The Legal System: A Social Science Perspective, [Pent. M. Khozim], Nusamedia, Bandung

[2] Sudikno Mertokusumo, 1999, Mengenal Hukum Suatu Pengantar. Liberty, Yogyakarta

[3] Mukti Fajar ND dan Yulianto Achmad, 2010, Dualisme Penelitian Hukum Normatif \& Empiris, Pustaka Pelajar, Yogyakarta.

[4] Burhan Bungin, 2001. Metode Penelitian Sosial, Format-format Kuantitatif Dan Kualitatif: Airlangga Unversity Press, Surabaya

[5] Pedoman tentang ADR dalam Kasus kecelakaan lalu lintas, Direktorat Lalu Lintas Kepolisian Negara Republik Indonesia Daerah Jawa Tengah 2010.

[6] Constitution of the Republic of Indonesia Of 1945

[7] Act No. 22 of 2009 Regarding Traffic and Road Transportation

[8] Act No. 2 of 2002 on Police

[9] National Police Chief Letter Nopol: B / 3022 / XII / 2009 / SDEOPS 14 December 2009 on the Handling of Cases through the Alternative Dispute Resolution (ADR)

[10] National Police Chief Pol letter No: B / 3022 / XII / 2009 / SDEOPS dated December 14, 2009 